\title{
A COMPARATIVE EVALUATION OF ANTI-DIABETIC POTENTIALITY FOUND IN DIFFERENT MARKETED POLYHERBAL FORMULATION USING GLUCOCORTICOID-INDUCED HYPERGLYCAEMIA IN RABBIT
}

\author{
PRANJAL BORUAH ${ }^{* 1}$, JASHABIR CHAKRABORTY ${ }^{1}$, SUVAKANTA DASH ${ }^{1}$ \\ ${ }^{1}$ Girijananda Chowdhury Institute of Pharmaceutical Science (GIPS), Azara, Guwahati, Assam 781017 \\ Email: pranjalbrh8@gmail.com
}

Received: 27 Jan 2017, Revised and Accepted: 20 Apr 2017

\begin{abstract}
Objective: The aim of this study was performed to evaluate Antidiabetic potentiality found in different marketed polyherbal formulation using glucocorticoid-induced hyperglycaemia in the rabbit.

Methods: The potentiality of different polyherbal formulation was investigated using dexamethasone (DEX) induced hyperglycaemia in Rabbit. Eight male rabbits were divided into four groups of two each. The first group is regarded as control group received $3 \mathrm{ml}$ of normal saline daily by using the gastric tube for $15 \mathrm{~d}$ and remaining three group received $(0.35 \mathrm{mg} / \mathrm{Kg}$ B.W. single dosage) of dexamethasone tablets which were powdered, dissolved in $3 \mathrm{ml}$ of normal saline daily for $15 \mathrm{~d}$. After $15 \mathrm{~d}$ the blood glucose estimated by using a glucometer and it is found that DXE treatment leads to significant increase in levels of glucose and a significant decrease in body weight. After that second group received metformin tablet. The third and fourth group received polyherbal formulation A and formulation B, which are powdered and dissolved in $3 \mathrm{ml}$ of normal saline daily for $15 \mathrm{~d}$ at the dose of $0.5 \mathrm{gm} / \mathrm{kg}$ body weight orally. After completion of regular administration for $15 \mathrm{~d}$, the blood glucose was again estimated and compare the results of each the group.
\end{abstract}

Conclusion: The Anti-diabetic polyherbal marketed formulations were having less side effect as compared to standard metformin tablet (e. g. body weight loss). And both the polyherbal formulations were found a therapeutic equivalence to each other, also having the approximately similar potentiality to standard metformin tablet.

Results: The result was found that the polyherbal marketed formulations were having less side effect as compared to standard metformin tablet (e. g. body weight loss). And both the polyherbal formulations were found significantly decreased in blood glucose level at equal potentiality, which can be consider as therapeutic equivalence to each other, and both the formulation also having the approximately similar potentiality to standard metformin tablet.

Keywords: Therapeutic equivalence, Polyherbal formulation, Dexamethasone, Hyperglycaemia

(C) 2017 The Authors. Published by Innovare Academic Sciences Pvt Ltd. This is an open access article under the CC BY license (http://creativecommons.org/licenses/by/4.0/) DOI: http://dx.doi.org/10.22159/ijcpr.2017v9i4.20964

\section{INTRODUCTION}

Diabetes mellitus is a group of heterogeneous disorder, where polyuria or excessive urine production is the most common initial significant. Diabetes mellitus is associated with less insulin secretion or less insulin sensitivity or both. And it leads to a reduction in carbohydrate metabolism increase in protein and lipid metabolism [1].

According to WHO, the prevalence of diabetes is likely to increase by $35 \%$ by the year of 2025 currently there are over 150 million diabetics worldwide and this is likely to increase to 300 million or more. Statistical projection about India suggests that the number of diabetics will rise from 15 million in 1995 to 79.4 million by 2025, making it the country with the highest number of diabetics in the world [2]. The effects of diabetes mellitus include long-term damage, dysfunction and failure of various organs. In its most severe forms, ketoacidosis or a hyperosmolar state may develop and lead to stupor, coma and, in absence of effective treatment, death. Often symptoms are not severe or may be absent, and consequently, hyperglycaemia sufficient to cause pathological and functional changes may be present for a long time before the diagnosis is made [3]. The long-term effects of diabetes mellitus include progressive development of the specific complications of retinopathy with potential blindness, nephropathy that may lead to renal failure, and neuropathy with risk of foot ulcers, amputation, Charcot joints, and features of autonomic dysfunction, including sexual dysfunction. People with diabetes are at increased risk of cardiovascular, peripheral vascular and cerebrovascular disease [4].

Type 2 diabetes mellitus (T2DM) is known as non-insulindependent diabetes mellitus T2DM is a chronic illness due to endocrine dysfunction which is known as insulin resistance. T2DM is a rapidly growing health concern in both developed and developing nations. In adults, type 2 diabetes accounts for about $90 \%$ to $95 \%$ of all diagnosed cases of diabetes [5]. The risk for developing type 2 diabetes is associated with older age, obesity, family history of diabetes, history of gestational diabetes, impaired glucose metabolism, physical inactivity etc [6]. Glucocorticoid hormones are also responsible for developing of T2DM. Glucocorticoids are cause various degrees of $\beta$-cell dysfunction, reducing insulin sensitivity and impairing $\beta$-cell function [7] by acting through glucocorticoid receptors which are also expressed on pancreatic $\beta$-cells. Glucocorticoids may also impair the uptake and the metabolism of glucose in $\beta$-cells through genomic actions which lead to a decrease in the efficacy of cytoplasmic $\mathrm{Ca} 2+$ on the exocytotic process of insulin secretory vehicles [8].

\section{MATERIALS AND METHODS}

\section{Selection of standard drug}

Metformin tablet was selected as a standard drug for this study. Each tablet contains Metformin Hydrochloride $0.5 \mathrm{gm}$.

\section{Collection of polyherbal formulation}

The two different marketed polyherbal formulation were collected from the ayurvedic medical store from Guwahati. They are selected based on their different composition. And both the composition contains an almost equal number of extract.

Composition of polyherbal formulation

(Each 100 gm contains the following extract) 
Table 1: Composition of both formulation A and B

\begin{tabular}{|c|c|c|c|}
\hline \multicolumn{2}{|c|}{ Formulation $>A$} & \multicolumn{2}{|c|}{ Formulation $>$ B } \\
\hline 1. & Gurmarpatti (GymnemaSylvestre)-20.0 gm & 1. & Meshashringi (Gymnemasylvestre)-15 gm \\
\hline 2. & Jamunguthli (Syzgiumcumini)-8.0 gm & 2. & Asana (Fterocarpusmarsupium)-10.0 gm \\
\hline 3. & Giloy (Tinosporacordifolia)-10.0 gm & 3. & Yashtimadhu (Glycyrrhizaglabra)-10.0 gm \\
\hline 4. & Karela (Momordicacharantia) -5.0 gm & 4. & Saptarangi (Caseariaesculenta)-10.0 gm \\
\hline 5. & Kattha (Acacia catechu $)-5.0 \mathrm{gm}$ & 5. & Jambu (Syzygiumcuminii)-10.0 gm \\
\hline 6. & Haldi(Curcuma longa)-5.0 Gm & 6. & Shatavari (Asparagus racemosus)-10.0 gm \\
\hline 7. & Amla (Emblicaofficinalis) $-5.0 \mathrm{gm}$ & 7. & Punarnava (Boerhaaviadiffusa)-6.0 gm \\
\hline 8. & Vijay Sar(Petrocarpusmarsupium)-5.0 gm & 8. & Mundi (Sphaeranthusindicus)-4.0 gm \\
\hline 9. & Tejpata (Cinnamomumtamala)-5.0 gm & 9. & Guduchi (Tinosporacordifolia)-4.0 gm \\
\hline 10. & Shatavari (Asparagus racemosus)-5.0 gm & 10. & Kirata (Swertiachirata)-4.0 gm \\
\hline 11. & SudhSilajit (Asphaltumpunjabicum)-5.0 gm & 11. & Gokshura (Tribulusterrestris)-4.0 gm \\
\hline 12. & NeemPatta (Azadirachtaindica) $-5.0 \mathrm{gm}$ & 12. & Bhumyaamlaki (Phyllanthusamarus)-4.0 gm \\
\hline 13. & GularpattiChurna (Ficusglomerata)-4.0 gm & 13. & Gambhari (Gmelinaarborea)-4.0 gm \\
\hline 14. & Kutki (Picrorhizakurroa)-4.0 gm & 14. & Karpasi (Gossypiumherbaceum)-3.0 gm \\
\hline 15. & Chitrakmool (Plumbagozeylanicum)-4.0 gm & 15. & Daruharidra (Berberisaristata)-1.0 gm \\
\hline 16. & Methi(Trigonellafoenum)-3.0 gm & 16. & Kumari (Aloe vera)-1.0 gm \\
\hline 17. & Bang Bhasm-1.0 gm & & \\
\hline 18. & YasadaBhasm-1.0 gm & & \\
\hline
\end{tabular}

\section{Experimental animal}

All the experiments were carried out by using adult male rabbits. Eight healthy adult male rabbits were brought from the animal house GIPS, body weight (1500-2000 gm) with the approval of the Institute Animal Ethics Committee (IAEC). Approval no is GIPS/IAEC/B. Ph/2017/5. Experimental animals were kept in individual cages under standard husbandry condition with alternate $12 \mathrm{~h}$ light/dark period with regular fedon green alfalfa and normal drinking water. And animal maintained in a normal temperature [9].

\section{Equipment}

One-touch simple select blood glucose monitoring system (Flextronics Industrial Co, Ltd) is used for determination blood glucose

\section{Experimental design}

Antidiabetic potentiality of different polyherbal formulation was investigated using dexamethasone (DEX) induced hyperglycaemia in Rabbit. Eight male rabbits were divided into four groups of two each. The first group is regarded as control group received $3 \mathrm{ml}$ of normal saline daily by using the gastric tube for $15 \mathrm{~d}$ and remaining three group received $(0.35 \mathrm{mg} / \mathrm{Kg}$ B.W. single dosage) of dexamethasone tablets which were powdered, dissolved in $3 \mathrm{ml}$ of normal saline daily for $15 \mathrm{~d}$. After $15 \mathrm{~d}$ the blood glucose estimated by using a glucometer and after that second group received metformin tablet and the third and fourth group received polyherbal formulation $\mathrm{A}$ and formulation $\mathrm{B}$, dissolved in $3 \mathrm{ml}$ of normal saline daily for $15 \mathrm{~d}$ at the dose of $0.5 \mathrm{gm} / \mathrm{kg}$ body weight orally. After $15 \mathrm{~d}$ again blood glucose was estimated and compared the results of each the group [9].

\section{RESULTS}

\section{Body weight}

The table 2 shows the body weight of control, DXE treated groups from zero days to $15 \mathrm{~d}$ of administration. Table no. 2 also shows the body weight after treated with the polyherbal formulation A, Formulation B and metformin for another $15 \mathrm{~d}$ in DXE induced hyperglycemic rabbit. The result reflects that dexamethasone causes a significant decrease in body weight after $15 \mathrm{~d}$ when compared with zero time in the same group, also dexamethasone combination with metformin causes a significant decrease in body weight in dose $0.5 \mathrm{~g} / \mathrm{kg}$ B.W. But at same dose the polyherbal formulation A and formulation B treated DXE induced hyperglycemic rabbit, the body weight was found similar with the control group after comparisons.

Table 2: Effect of dexamethasone, metformin, formulation $>A$ and formulation $>B$ on body weight of male rabbits

\begin{tabular}{|c|c|c|c|c|}
\hline Treatments & Initial body weight in gm & $5^{\text {th }}$ day & 10 $0^{\text {th }}$ day & $15^{\text {th }}$ day \\
\hline 1. Control (Normal saline) (1 ${ }^{\text {st }}$ group) & 1750.66 & 1781.10 & 1793.50 & 1802.35 \\
\hline 2. Dexamethasone treated $(0.35 \mathrm{mg} / \mathrm{kg}$ B.W. $)\left(2^{\text {nd }}\right.$ group $)$ & 1740.30 & 1714.45 & 1650.70 & 1580.27 \\
\hline 3. Dexamethasone treated $(0.35 \mathrm{mg} / \mathrm{kg} \mathrm{B.W})$ ( $3^{\text {rd }}$ group) & 1770.80 & 1735.20 & 1695.65 & 1650.91 \\
\hline 4. Dexamethasone $(0.35 \mathrm{mg} / \mathrm{kg} \mathrm{B.W}).\left(4^{\text {th }}\right.$ group) & 1812.10 & 1782.59 & 1736.34 & 1696.43 \\
\hline 5. Standard treated metformin $(0.5 \mathrm{~g} / \mathrm{kg} \mathrm{B.} \mathrm{W})\left(2^{\text {nd }}\right.$ group $)$ & 1580.27 & 1562.30 & 1525.68 & 1488.30 \\
\hline 6. Poly herbal formulation $>$ A treated $(0.5 \mathrm{~g} / \mathrm{kg} \mathrm{B.} \mathrm{W})$ ( $3^{\text {nd }}$ group $)$ & 1650.91 & 1663.94 & 1709.73 & 1740.87 \\
\hline 7. Poly herbal formulation $>B$ treated $(0.5 \mathrm{~g} / \mathrm{kg} \mathrm{B.} \mathrm{W})\left(4^{\text {th }}\right.$ group $)$ & 1696.43 & 1712.34 & 17748.90 & 1767.56 \\
\hline
\end{tabular}

Table 3: Effect of dexamethasone, metformin, formulation $>A$ and formulation $>B$ on glucose profile of male rabbits

\begin{tabular}{|c|c|}
\hline Treatments & Glucose (mg/dl) \\
\hline 1. Control (Normal saline) (1 $1^{\text {st }}$ group) & 108.24 \\
\hline 2. Dexamethasone-treated (0.35 mg/kg B.W.)(2 ${ }^{\text {nd }}$ group) & 159.60 \\
\hline 3. Dexamethasone-treated ( $0.35 \mathrm{mg} / \mathrm{kg}$ B.W. $)\left(3^{\text {rd }}\right.$ group) & 162.42 \\
\hline 4. Dexamethasone $(0.35 \mathrm{mg} / \mathrm{kg} \mathrm{B.W.})\left(4^{\text {th }}\right.$ group $)$ & 154.89 \\
\hline 5. Standard treated metformin ( $0.5 \mathrm{~g} / \mathrm{kg} \mathrm{B.} \mathrm{W})$ ( $2^{\text {nd }}$ group $)$ & 101.36 \\
\hline 6. Polyherbal formulation $>A$ treated $(0.5 \mathrm{~g} / \mathrm{kg} \mathrm{B.} \mathrm{W})$ (3nd group) & 105.04 \\
\hline 7. Polyherbal formulation $>B$ treated $(0.5 \mathrm{~g} / \mathrm{kg} \mathrm{B.} \mathrm{W})$ ( $4^{\text {th }}$ group) & 107.20 \\
\hline
\end{tabular}

\section{Blood glucose level}

(Effect of dexamethasone, metformin, formulation A and formulation B on glucose profile of male rabbits) table 3 shows the dexamethasone treated $(0.35 \mathrm{mg} / \mathrm{kg} \mathrm{B.} \mathrm{W})$ animal groups causes a significant increase in blood glucose level in rabbits when compared to control group, also the table indicates that the treatment with standard metformin tablet, polyherbal formulation $\mathrm{A}$ and formulation $\mathrm{B}$ at the same dose at $0.5 \mathrm{~g} / \mathrm{kg} \mathrm{B}$. W causes a significant decrease in glucose level. And blood sugar controlling potentiality or ant diabetic potentiality of both polyherbal formulation A and formulation B were found significantly effective and similar with the standard metformin tablet.

These results also compared in the fig. 1 with a graphical presentation. 


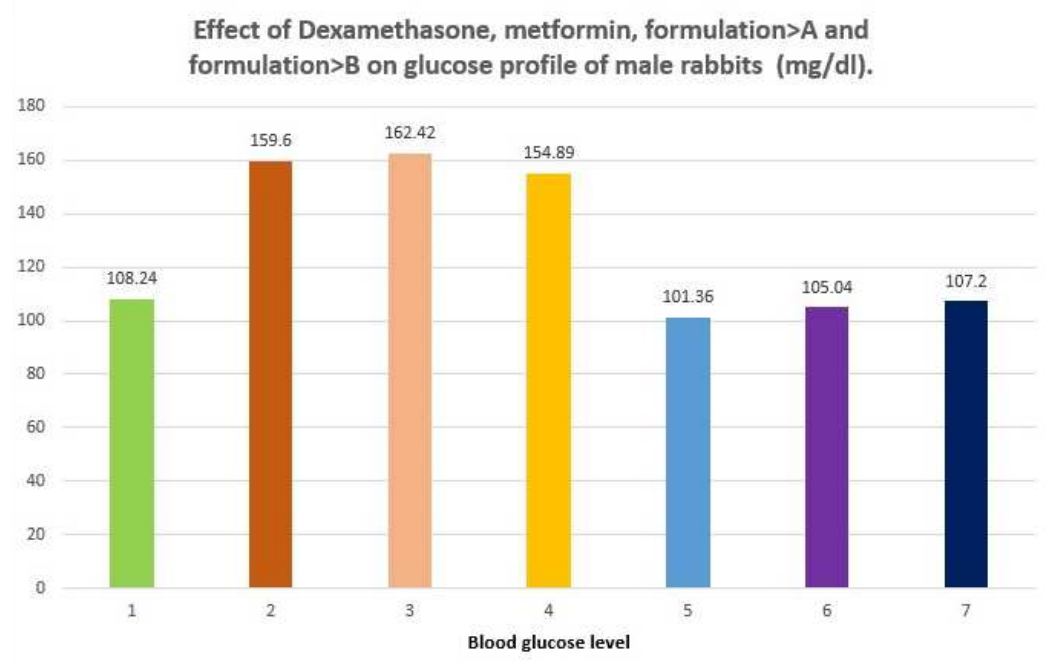

Fig. 1: Effect of dexamethasone, metformin, formulation $>A$ and formulation $>$ B on glucose profile of male rabbits) (According to table 3)

\section{DISCUSSION}

Use of marketed polyherbal formulation is a good choice of treatment in type 2 diabetes mellitus (T2DM). Because polyherbal medicines are usually derived from natural plants, they are considered to be relatively safe and have fewer side effects with affordable price than the synthetic or conventional drugs. The synthetic drug which are used in the management T2DM with fewer side effects at lower costs is still a big challenge. These medications frequently have side effects, such as weight loss, bone loss, and increased risk of cardiovascular events [10]. These side effects could become more prevalent due to continuous use. Furthermore, treatment is very costly as well, since T2DM is a chronic disease and long-term medications are necessary. Polyherbal medications can be a good alternative to replace or at least supplement to standard medications $[11,12]$.

Polyherbal medications treating T2DM can target multiple mechanisms including enhancement of insulin sensitivity, stimulation of insulin secretion, or reduction of carbohydrate absorption [11]. Unlike standard medicine which usually contains a single active ingredient aiming for a specific mechanism, herbal concoctions may contain various active ingredients targeting multiple mechanisms. Standard drugs are sometimes more potent than herbal medicine in lowering blood glucose levels. However, herbal supplements have shown to be able to treat diabetic complications [13]. Thus herbal medicine can also be used as supplementation or in combination with the standard medicine to improve better therapeutic outcomes.

\section{CONCLUSION}

The Anti-diabetic polyherbal marketed formulations were having less side effect as compared to standard metformin tablet (e. g. body weight loss). And both the polyherbal formulations were found a therapeutic equivalence to each other, also having the approximately similar potentiality to standard metformin tablet.

According to above results, it can be concluded that polyherbal formulation are useful in the management of diabetes as standard metformin tablet with having less side effect.

\section{CONFLICT OF INTERESTS}

Declare none

\section{REFERENCES}

1. Wild S, Roglic G, Green A, Sicree R, King H. Global prevalence of diabetes: estimates for the year 2000 and projections for 2030 . Diabetes Care 2004;27:1047-53.

2. Rajasekaran S, Jaykar B, Anandan R, Aboobackersidheeq KP, Vannamalar S. Anti-diabetic activity of leaves of
Zizyphusnummularia by dexamethasone-induced diabetic rat model. Int J PharmTech Res 2013;5:844-51.

3. Pediatr J. Effect of intensive diabetes treatment on the development and progression of long-term complications in adolescents with insulin-dependent diabetes mellitus: diabetes control and complications trial. D Ctrl Complications Trial Res GRP 1994;2:125-7.

4. National Diabetes Data Group: Classification and diagnosis of diabetes mellitus and other categories of glucose intolerance. Diabetes Care 1979;28:1039-57.

5. Zimmet P, Alberti K, Shaw J. Global and societal implications of the diabetes epidemic. Nature 2011;41:782-7.

6. Devegt F, Dekker J, Stehouwer C, Nijpels G, Bouter L, Heine R. The 1997 American Diabetes Association criteria versus the 1985 World Health Organization criteria for the diagnosis of abnormal glucose tolerance, poor agreement in the Hoorn Study. Diabetes Care 1998;21:1686-90.

7. Raalte V, Ouwens DM, Diamant M. Novel insights into glucocorticoid-mediated diabetogenic effects: towards the expansion of therapeutic options. Eur J Clin Investigation 2009;39:81-93.

8. Seino $\mathrm{S}$, Shibasaki $\mathrm{T}$, Minami $\mathrm{K}$, Pancreatic $\beta$-cell signalling: toward a better understanding of diabetes and its treatment. Proc Jpn Acad 2010;86:563-77.

9. Muna H, Saeed A. Amelioration effect of methanolic extract of Cyperusrotundus on type 2 diabetes mellitus, thyroid dysfunction and gallstone induce by dexamethasone in male rabbits. Kufa J Veterinary Med Sci 2016;7:102-18.

10. AHFS Drug Information, Authority of the Board of the American Society of Health-System Pharmacists, American Hospital Formulary Service, Bethesda USA; 2012.

11. Zheng H, Bukuru J, Kimpe N. Natural medicines used in the traditional Chinese medical system for therapy of diabetes mellitus. J Ethnopharmacol 2004;92:1-21.

12. Jia W, Gaoz W, Tang L. Antidiabetic herbal drugs officially approved in China. Phytother Res 2003;17:1127-34.

13. Ceylan A, Fliethman R, Wold L, Ren J. Herbal and traditional Chinese medicine for the treatment of cardiovascular complications in diabetes mellitus. Curr Diabetes Rev 2008;4:320-8.

\section{How to cite this article}

- Pranjal Boruah, Jashabir Chakraborty, Suvakanta Dash. A comparative evaluation of anti-diabetic potentiality found in different marketed polyherbal formulation using glucocorticoidinduced hyperglycaemia in rabbit. Int J Curr Pharm Res 2017;9(4):83-85. 